\title{
Placental abruption an obstetric emergency: management and outcomes in 180 cases
}

\author{
Pratibha Devabhaktuni $^{1 *}$, Aruna Kumari Konkathi ${ }^{2}$
}

\begin{abstract}
${ }^{1}$ Department of Obstetrics and Gynecology, Modern Government Maternity Hospital/Osmania Medical College, Hyderabad, Telangana, India

${ }^{2}$ Department of Obstetrics and Gynecology, Niloufer Hospital for Women and Children/Osmania Medical College, Hyderabad, Telangana, India
\end{abstract}

Received: 13 July 2020

Accepted: 18 July 2020

\section{*Correspondence: \\ Dr. Pratibha Devabhaktuni, \\ E-mail:dpdnk@yahoo.com}

Copyright: (C) the author(s), publisher and licensee Medip Academy. This is an open-access article distributed under the terms of the Creative Commons Attribution Non-Commercial License, which permits unrestricted non-commercial use, distribution, and reproduction in any medium, provided the original work is properly cited.

\section{ABSTRACT}

Background: During a period of eight months, 180 cases of abruption that occurred from January 2007 to August 2007 at GMH, Nayapool, Hyderabad were analysed. Total number of deliveries during the study period of eight months were 14004. Incidence of abruption cases delivered was - $1.3 \%$. In this series $88 \%$ were unbooked in our hospital, were referrals. Objective of this study was to study maternal fetal outcome of placental abruption.

Methods: Initial clinical assessment, investigations for maternal fetal wellbeing, expedite delivery, manage complications as per accepted protocol. In this series of cases, ARM was done in 85 cases (47.22\%), ARM was done and oxytocin drip was started in $36(20 \%)$, ARM was done and PGE1 tablet $25 \mathrm{mcg}$. was inserted in the vagina in 39 $(21.66 \%)$.

Results: The bleeding was revealed in $146-81.1 \%$ and concealed in $34-18.88 \%$. The number of cases with hypertension complicating pregnancy were $102-57 \%$, hypotension in $16-8.88 \%$, prolonged clotting time $13-7.22 \%$, the number of patients who received blood transfusions were $105(58.3 \%)$, number of patients who received fresh frozen plasma, FFP transfusions were $65-36.11 \%$. Taken for LSCS at admission were - 46. Failure to progress after ARM or other methods of labour augmentation were 20 cases. The total number of caesarean deliveries were 66/180 $(36.66 \%)$, number of vaginal deliveries were $114(63.33 \%)$. Perinatal outcome: the total number of intra uterine fetal deaths (IUFD) at admission were 103-57.2\%. The number of still births were 7-3.8\%. Live born babies were 70$38.8 \%$. Neonatal deaths were $11-6.1 \%$ and total perinatal deaths were 121-67.2\%. (IUFD at admission-103, + still births $-7,+$ neonatal deaths $-11=121$ perinatal deaths. There were five maternal deaths in 180 cases of placental abruption, $2.7 \%$ mortality.

Conclusions: Need to consider measures to reduce the occurrence of this condition.

Keywords: Antepartum haemorrhage, Perinatal mortality, Placental abruption, Prematurity

\section{INTRODUCTION}

Placental abruption traditionally is defined as the premature separation of the implanted placenta before the delivery of the fetus. Of 66,459 deliveries, $667(1 \%)$ were cases of placental abruption. ${ }^{1}$ In a cohort of $27,796,465$ singleton births, (USA) the prevalence rates of mild and severe abruption were 3.1 and 6.5 per 1000 , respectively (overall prevalence rate, 9.6 per 1000). ${ }^{2}$

Overall, as per Downes et al, the reported incidence of abruption in the reviewed literature ranged from 0.01 to 
$5.1 \%$, but the majority of studies had an incidence ranging from 0.5 to $1.0 \% .^{3}$

During a period of eight months, 180 cases of placental abruption occurred from January 2007 to August 2007 at GMH, Nayapool, Hyderabad. Total number of deliveries during the study period of eight months were 14004 Incidence of abruption cases delivered was $-1.3 \%$ in this study. Approximately 50 to $80 \%$ of preterm births in the setting of abruption are spontaneous (preterm labor or membrane rupture), but abruption is also considered the fourth most common cause of medically indicated preterm birth. ${ }^{4,5}$

Preterm birth (<37 weeks) was one of the most frequently reported outcomes associated with abruption, more than half $(55 \%)$ of excess perinatal deaths associated with abruption are attributed to preterm birth. ${ }^{2,6}$

The high perinatal mortality as a result of intra uterine fetal deaths, stillbirths, neonatal deaths and also the delayed sequelae of neuro developmental deficits in children later in life, make it an obstetric emergency with immediate mortality and late consequences to both mother and the neonate. ${ }^{7-10}$

A greater attention needs to be paid to this obstetric condition. Once placental abruption occurs, the perinatal outcome may not be dependent on management alone. Hence prevention of the occurrence of abruption may be the way to move forward. The beneficial effect of folic acid supplementation in reducing abruptions is well documented. There are reports from countries that reduction in smoking had an effect on the incidence of abruption placenta.

Alcohol and cocaine consumption also would impact the occurrence. Measures aimed at reducing the hypertensive disorders of pregnancy, may have a role, as HDP is a known associated high-risk condition. ART procedures aimed at single embryo transfer would reduce twinning and multiple pregnancies with resultant reduction in obstetric complications.

\section{METHODS}

During a period of eight months, 180 cases of abruption that occurred from January 2007 to August 2007 at GMH, Nayapul, Hyderabad were analyzed. Total number of deliveries during the study period of eight months were 14004. Incidence of abruption cases delivered was $1.3 \%$. In this series $88 \%$ were unbooked in the study hospital, but were having antenatal care elsewhere.

\section{Inclusion criteria}

- Pregnant women with antepartum bleeding associated with abdominal pain, from 28 weeks of gestation till term gestation.

\section{Exclusion criteria}

- Pregnant women with placenta previa, women with antepartum bleeding due to cancer cervix, cervical polyp, vaginal infection, pregnant women with bleeding per rectum due to piles.

- Bleeding per vaginum, not due to detachment of a placenta, but due to other causes were excluded.

\section{Investigations}

Hemoglobin, complete blood count, complete urine examination, renal function tests, liver function tests, platelet count, bedside clotting time, bleeding time, and emergency obstetric scan when feasible. Coagulation profile was done in needed cases. Diagnosis was made by clinical observations and in some cases, ultrasound examination to assess the retroplacental clot, to exclude placenta previa and fetal status.

\section{Mode of induction, augmentation, acceleration of labour}

If the cervix is effaced and dilated, even admitting a finger, artificial rupture of the membranes (ARM) would be done with a spinal needle.

Earlier decades ARM was done using a Kochers forceps. But a spinal needle is more convenient, light in weight and can perform ARM with less cervical dilatation.

ARM would hasten delivery, relieve intra uterine pressure and blood-stained liquor would confirm the diagnosis of abruption. After ARM, clear liquor does not exclude abruption, if the retro placental clot and bleeding do not communicate with amniotic fluid.

Some cases would be taken up for abdominal delivery at admission and in some who do not progress in labour and the response to labour augmentation was tardy and unsatisfactory in the next four to six-hour period, would have to be taken for $\mathrm{C}$.

Authors stress the need to reassess the case response to management at half hourly intervals.

In patients with a coagulation disorder when would you operate? After infusion of blood products, the clotting parameters would be corrected, immediately a caesarean delivery can be undertaken. Simultaneous arrangements have to be in progress.

\section{RESULTS}

\section{Presenting complaints}

The bleeding was revealed in $146-81.1 \%$ and concealed in $34-18.88 \%$. Women presented with reduced fetal movements 20, pain abdomen 11, Preterm rupture of 
membranes, PROM 1, imminent symptoms of eclampsia in 2 Table 1.

\section{Gravida, para, status}

Primies - 37, second gravida - 62, third gravida - 47, fourth gravida - 22, fifth gravida - 12 Table 2 .

Table 1: Presenting features of placental abruption.

\begin{tabular}{|ll|}
\hline Presenting complaint & Number \\
\hline Bleeding PV & 146 \\
\hline Revealed hemorrhage & 146 \\
\hline Concealed hemorrhage & 34 \\
\hline Reduced fetal movements & 20 \\
\hline Pain abdomen & 11 \\
\hline PROM & 1 \\
\hline Imminent symptoms of eclampsia & 2 \\
\hline
\end{tabular}

Table 2: Gravida, para, status.

\begin{tabular}{|lll|}
\hline Gravida & No. of cases & $\%$ \\
\hline Primies & 37 & $20.55 \%$ \\
\hline Second gravida & 62 & $34.44 \%$ \\
\hline Third gravida & 47 & $26.11 \%$ \\
\hline Fourth gravida & 22 & $12.22 \%$ \\
\hline Fifth gravida & 12 & $6.66 \%$ \\
\hline
\end{tabular}

Table 3: Age of women with abruption.

\begin{tabular}{|ll|}
\hline Age in years & Number \\
\hline $20-25$ & 130 \\
\hline $26-30$ & 30 \\
\hline$>30$ & 20 \\
\hline
\end{tabular}

Table 4: Gestational age at abruption.

\begin{tabular}{|lll|}
\hline Gestation in weeks & Number & $\%$ \\
\hline $20-28$ & 10 & $5.55 \%$ \\
\hline $28-32$ & 40 & $22.22 \%$ \\
\hline $32-36$ & 89 & $49.44 \%$ \\
\hline$>36$ & 41 & $22.77 \%$ \\
\hline
\end{tabular}

Table 5: Placental abruption: associated risk factor/complication.

\begin{tabular}{|lll|}
\hline $\begin{array}{l}\text { Associated risk } \\
\text { factor/complication }\end{array}$ & Number & $\%$ \\
\hline $\begin{array}{l}\text { No of cases with high blood } \\
\text { pressure }\end{array}$ & 102 & $57 \%$ \\
\hline Mild PIH & 70 & $38.88 \%$ \\
\hline Severe PIH & 32 & $17.77 \%$ \\
\hline Normal blood pressure & 62 & $34.44 \%$ \\
\hline Hypotension & 16 & $8.88 \%$ \\
\hline Prolonged clotting time & 13 & $7.22 \%$ \\
\hline Received blood transfusions & 105 & $58.3 \%$ \\
\hline Received FFP transfusions & 65 & $36.11 \%$ \\
\hline
\end{tabular}

\section{Age distribution}

In the age group of 20-25 years there were 130 women, 26-30 years - 30 and more than 30 years - 20 women in the study Table 3 .

\section{Antenatal care}

Twenty of the patients with abruption were booked cases in Government Maternity Hospital, Hyderabad, and 160 were referrals, but all of them had antenatal care in other health facilities.

Table 6: Mode of labour induction and augmentation of labour.

\begin{tabular}{|lll|}
\hline $\begin{array}{l}\text { Method of labour induction } \\
\text { and augmentation }\end{array}$ & $\begin{array}{l}\text { Number } \\
\mathbf{1 6 0}\end{array}$ & $\%$ \\
\hline $\begin{array}{l}\text { Artificial rupture of } \\
\text { membranes ARM }\end{array}$ & 85 & $47.22 \%$ \\
\hline ARM + Oxytocin & 36 & $20 \%$ \\
\hline ARM + PGE1 & 39 & $21.66 \%$ \\
\hline
\end{tabular}

Table 7: Induction delivery interval.

\begin{tabular}{|lll|}
\hline Number of hours & $\begin{array}{l}\text { Number of cases } \\
(\mathbf{n = 1 8 0})\end{array}$ & $\%$ \\
\hline$<6$ & 116 & $64.44 \%$ \\
\hline $6-12$ & 48 & $26.66 \%$ \\
\hline $12-18$ & 10 & $5.55 \%$ \\
\hline $18-24$ & 6 & $3.33 \%$ \\
\hline
\end{tabular}

Table 8: Indications for LSCS.

\begin{tabular}{|ll|}
\hline Indication for LSCS & $\mathbf{N}=\mathbf{6 6}$ \\
\hline LSCS at admission & 46 \\
\hline Live fetus & 23 \\
\hline Previous one caesarean & 17 \\
\hline Two previous caesareans & 4 \\
\hline Placenta praevia with abruption & 2 \\
\hline $\begin{array}{l}\text { Failure to progress after ARM + } \\
\text { augmentation }\end{array}$ & 20 \\
\hline
\end{tabular}

\section{Abruption with associated preeclampsia}

The number of cases with hypertension complicating pregnancy were $102-57 \%$, severe preeclampsia in $32 / 180-17.77 \%$. Normal blood pressure was recorded in $62-34.44 \%$ at admission.

\section{Other complications}

The number of women admitted with complications, hypotension in $16-8.88 \%$, prolonged clotting time $13-$ $7.22 \%$, the number of patients who received blood transfusions were $105(58.3 \%)$, number of patients who received fresh frozen plasma, FFP transfusions were 65$36.11 \%$ Table 4 . 


\section{Duration of gestation when placental abruption occurred}

The period of gestation when placental separation occurred was 20-28 weeks in 10 (5.55\%), 28-32 weeks in $40(22.22 \%), 32-36$ weeks in $89(49.44 \%)$, and more than 36 weeks in $41(22.77 \%)$ Table 5.

\section{Mode of induction, augmentation/acceleration of labour}

In this series of cases, ARM was done in 85 cases $(47.22 \%)$, ARM was done and oxytocin drip was started in $36(20 \%)$, ARM was done and PGE1 tablet $25 \mathrm{mcg}$. was inserted in the vagina in $39(21.66 \%)$ Table 6.

\section{Induction delivery interval $(n=180)$}

Induction delivery interval was less than 6 hours in 116$64.44 \%, 6-12$ hours, in 48 (26.66\%), 12-18 hours, in 10 $(5.55 \%), 18-24$ hours in $6(3.33 \%)$ Table 7.

\section{Route of delivery}

The total number of caesarean deliveries were 66/180 $(36.66 \%)$, number of vaginal deliveries were 114 $(63.33 \%)$, hysterotomy - $4(2.22 \%)$.

\section{Immediate LSCS}

Taken for LSCS at admission were - 46. The indications for immediate LSCS were a live fetus in 23, previous one caesarean in 17 , two previous caesareans in 4 , placenta previa with abruption in two cases Table 8.

\section{Failure to progress}

After ARM or other methods of labour augmentation were 20 cases.

Table 9: Birth weight distribution.

\begin{tabular}{|l|l|}
\hline Birth weight in $\mathrm{kg}$ & Number \\
\hline Around $1 \mathrm{~kg}$ & 24 \\
\hline $1-1.5$ & 53 \\
\hline $1.6-2$ & 44 \\
\hline $2.1-2.5$ & 42 \\
\hline $2.6-3$ & 17 \\
\hline
\end{tabular}

\section{Birth weight distribution}

Total number of term babies were - $47-26.11 \%$, preterm babies - $133-73.88 \%$. Birth weight around $1 \mathrm{~kg}$ were 24 , $1.1 \mathrm{n} 1.5 \mathrm{~kg}$ were $53,1.6-2 \mathrm{~kg}$ were $44,2.1-2.5 \mathrm{~kg}$ were 42, 2.6 - $3 \mathrm{~kg}$ were 17 , Table 9 .

\section{Perinatal outcome}

The total number of intra uterine fetal deaths at admission were $103-57.2 \%$. The number of still births were $7-3.8 \%$. Live born babies were $70-38.8 \%$. Neonatal deaths were $11-6.1 \%$ and total perinatal deaths were 121-67.2\%. (IUFD at admission - 103, + still births - 7, + neonatal deaths $-11=121$ perinatal deaths) Table 10 .

In the final analysis the number of babies survived was $59 / 180=32.77 \%$.

Table 10: Perinatal outcome.

\begin{tabular}{|lllllll|}
\hline Fetus alive/death & $\begin{array}{l}\text { Total } \\
\text { number }\end{array}$ & $\begin{array}{l}\text { Total } \\
\%\end{array}$ & $\begin{array}{l}\text { Vaginal delivery } \\
\text { no. } \mathbf{1 1 4}\end{array}$ & $\begin{array}{l}\text { Vaginal delivery } \\
\%\end{array}$ & $\begin{array}{l}\text { Caesarean } \\
\text { No.-66 }\end{array}$ & $\begin{array}{l}\text { LSCS } \\
\text { delivery } \%\end{array}$ \\
\hline IUD at admission & 103 & $57.2 \%$ & 76 & $42.2 \%$ & 27 & $15 \%$ \\
\hline Total still births & 7 & $3.8 \%$ & 3 & $1.6 \%$ & 4 & $2.2 \%$ \\
\hline Total live babies & 70 & $38.8 \%$ & 35 & $19.4 \%$ & 35 & $19.4 \%$ \\
\hline Total neonatal deaths & 11 & $6.1 \%$ & 6 & $3.3 \%$ & 5 & $2.7 \%$ \\
\hline Total perinatal deaths & 121 & $67.2 \%$ & 85 & $47.2 \%$ & 36 & $20 \%$ \\
\hline Total NICU admissions & 50 & $27.7 \%$ & - & - & - & - \\
\hline
\end{tabular}

\section{Complications}

Postpartum haemorrhage had to be managed in - 7 cases (4 during LSCS), (3 during vaginal), B lynch compression sutures were applied in 4 cases. Eclampsia and imminent eclampsia were associated in 4 cases, HELLP syndrome in one case.

Post-operative burst abdomen occurred in one case; caesarean hysterectomy was not performed in any Table 11.

\section{Maternal mortality}

There were five maternal deaths in 180 cases of placental abruption, $2.7 \%$ mortality. Three of the deaths occurred in primies, two in third pregnancy.

One had antepartum eclampsia, who was unconscious at admission with IUD and clotting defect. Another was a case of preeclampsia with HELLP syndrome and clotting defect, in spite of multiple blood products transfusion and caesarean delivery, the DIC continued and hypotension 
persisted. Two cases, one a third gravida, another a primi, both died undelivered within two hours of admission. Both had hypotension, IUD, and clotting defect.

One third gravida admitted with IUD, clotting defect, blood products were transfused, LSCS was done, she died 16 hours later due to ARDS, clotting defect Table 12.
Table 11: Placental abruption: complications.

\begin{tabular}{|ll|}
\hline Associated complication & Number \\
\hline Postpartum haemorrhage & 7 \\
\hline Eclampsia and Imminent eclampsia & 4 \\
\hline HELLP syndrome & 1 \\
\hline Post-operative burst abdomen & 1 \\
\hline
\end{tabular}

Table 12: Maternal mortality in placental abruption - 180 cases maternal mortality - total number of maternal deaths $5(2.7 \%)$.

\begin{tabular}{|c|c|c|c|}
\hline Parity & Condition at the time of admission & Measures taken & $\begin{array}{l}\text { Admission } \\
\text { death interval }\end{array}$ \\
\hline G3 P2 L2 with 9 mA & $\begin{array}{l}\text { H/O bleeding PV with IUD, BP } 70 \\
\text { mm Hg systolic, clotting time - } 20 \text { min }\end{array}$ & $\begin{array}{l}1 \text { unit of blood given, dopamine } \\
\text { drip }\end{array}$ & $\begin{array}{l}1 \mathrm{hr} 10 \mathrm{~min} \text {, died } \\
\text { undelivered }\end{array}$ \\
\hline G3 P2 L2 with $9 \mathrm{~mA}$ & $\begin{array}{l}\text { Came with bleeding PV with IUD, BP } \\
130 / 90 \mathrm{mmHg}, \mathrm{CT}-6 \mathrm{~min} \text {, cervix } 1 / 2- \\
\text { inch-long, os } 2 \mathrm{f} \text {, clotting time }-15 \mathrm{~min}\end{array}$ & $\begin{array}{l}\text { ARM + PGE1, } 4 \text { units of blood, } \\
4 \text { units of FFP, Emerg. LSCS } \\
\text { done, post op hypotension, CT } \\
\text { prolonged, lungs - basal crepts }\end{array}$ & $\begin{array}{l}16 \text { hrs, cause of } \\
\text { death shock, } \\
\text { DIC, ARDS }\end{array}$ \\
\hline Primi 28 weeks & $\begin{array}{l}\text { History of bleeding PV with IUD, } 80 \\
\text { mmHg systolic, Cx long os closed, CT } \\
\text { - } 15 \text { min }\end{array}$ & $\begin{array}{l}1 \text { unit of blood transfusion, } \\
\text { haemaccel started } \mathrm{O} 2 \text { inhalation }\end{array}$ & $\begin{array}{l}2 \mathrm{hrs}, \mathrm{DIC} \text { and } \\
\text { shock died } \\
\text { undelivered }\end{array}$ \\
\hline Primi 37 weeks & $\begin{array}{l}\text { Came with bleeding PV and IUD, Cx } \\
\text { log os closed, BP } 130 / 90 \mathrm{mmHg} \text {, } \\
\text { Increased serum bilirubin, Increased } \\
\text { Liver enzymes, CT - } 10 \text { min }\end{array}$ & $\begin{array}{l}6 \text { units of blood, } 4 \text { units of FFP, } \\
\text { Em LSCS done, couvelair } \\
\text { uterus, post op hypotension, dIC }\end{array}$ & $\begin{array}{l}8 \text { hrs, HELLP } \\
\text { syndrome, DIC }\end{array}$ \\
\hline $\begin{array}{l}\text { Primi } 36 \text { weeks with } \\
\text { antepartum eclampsia }\end{array}$ & $\begin{array}{l}\text { Came with bleeding PV and } \\
\text { convulsions, BP - } 150 / 120 \mathrm{mmHg}, \mathrm{CT} \\
\text { - 10min, unconscious IUD } 36 \text { weeks, } \\
\mathrm{CX} 1 / 2 \text { inch long, os } 1 \mathrm{f}\end{array}$ & $\begin{array}{l}\text { ARM done, oxytocin drip given, } \\
\text { hypotension, } 2 \text { unit of blood, } 2 \\
\text { units of FFP given }\end{array}$ & $\begin{array}{l}5 \mathrm{hr} 30 \mathrm{~min} \text {, } \\
\text { DIC, antepartum } \\
\text { eclampsia, died } \\
\text { undelivered }\end{array}$ \\
\hline
\end{tabular}

In a public sector hospital, the patients in the lower socioeconomic strata would get admitted, difficulty and delay in procuring blood is one of the reasons, being unable to provide timely massive blood transfusions.

In this series $88 \%$ were unbooked in our hospital, but were having antenatal care elsewhere.

\section{DISCUSSION}

Majority of placental abruptions occurred after 32 weeks of gestation, 130/180 cases, $72.22 \%$.

The maximum number of cases of severe preeclampsia, imminent and eclampsia also occur after 32 weeks of gestation. The period of gestation $(n=654)$, gestational age was less than 28 weeks in 86 (13.14\%), 28-34 weeks in $228(34.86 \%)$ and more than 34 weeks in 340 $(51.98 \%)$ cases. $^{11}$

Both these pathologic conditions affecting pregnancy occur in the third trimester of pregnancy leading to preterm delivery and increased perinatal mortality and maternal morbidity and mortality.

\section{The concealed variety}

In women having antepartum bleeding the diagnosis would be obvious, in those without bleeding per vaginum, the concealed variety, would complain of pain abdomen, reduced fetal movements, or may get admitted for other complaints like preterm rupture of membranes or symptoms of imminent eclampsia and during clinical examination and ultrasound, the abruption of placenta would be evident, leading to abnormalities in foetal heart rate.

\section{Mode of induction, augmentation/acceleration of labour}

ARM would hasten delivery, relieve intra uterine pressure and blood-stained liquor would confirm the diagnosis of abruption. After ARM, clear liquor does not exclude abruption, if the retro placental clot and bleeding do not communicate with amniotic fluid.

The main obstetric goal would be to expedite delivery, as the maternal complications and fetal are related to the abruption delivery interval. In this series of cases, ARM was done in 85 cases $(47.22 \%)$, ARM was done and 
oxytocin drip was started in $36(20 \%)$, ARM was done and PGE1 tablet $25 \mathrm{mcg}$. was inserted in the vagina in 39 $(21.66 \%)$. In our previous study, labour was induced and augmented with PGE1 vaginal tab. ${ }^{12}$ In 49 cases of placental abruption, with vaginal delivery in 40 and Csection in 9 cases.

If the abruption to delivery interval is shortened, intra uterine hypoxia of the fetus can be minimized with better perinatal survival.

To prevent maternal complications secondary to placental abruption, renal failure, disseminated intravascular coagulation (DIC) due to depletion of the clotting factors that are utilized in the formation of the retro placental clot, hypotension due to continued bleeding, the abruption to delivery interval has to be reduced.

\section{Induction delivery interval}

Induction delivery interval would be the same as admission delivery interval. Much more significant would be abruption delivery interval which will have greater impact on the complication rate. The aim of management of any case of placental abruption would be to minimize the abruption delivery interval.

\section{Route of delivery}

Some cases would be taken up for abdominal delivery at admission and in some who do not progress in labour and the response to labour augmentation was tardy and unsatisfactory in the next four to six-hour period would have to be taken for C-section.

Authors need to reassess the case response to management at half hourly intervals.

The situations when authors would choose an abdominal delivery at admission would be when the fetus is alive with abnormal CTG patterns, if cervix is unfavorable, long cervix with closed os, the patient already in hypotension and shock, with coagulation defect, prolonged CT BT, prothrombin time and hypofibrinogenemia and evidence of reduced urine output, elevated serum creatinine, acute AKI secondary to abruption, when the hematocrit shows severe acute anemia. For CPD, abnormal presentations, previous abdominal delivery and other obstetric indications.

In patients with a coagulation disorder when would you operate ? After infusion of blood products, the clotting parameters would be corrected, immediately a caesarean delivery can be undertaken.

Should never attempt an operative delivery without correction of the clotting defect as we would face uncontrolled bleeding on the operating table and risk losing the patient.

\section{When considering placental abruption, authors are worried about}

\section{Maternal mortality}

There were five maternal deaths in 180 cases of placental abruption, $2.7 \%$ mortality.

\section{Perinatal mortality}

The total number of intra uterine fetal deaths at admission were $103-57.2 \%$. The number of still births were $7-3.8 \%$. Live born babies were 70-38.8\%. Neonatal deaths were $11-6.1 \%$ and total perinatal deaths were 121-67.2\% (IUD at admission-103, + still births $-7,+$ neonatal deaths $-11=$ $121 / 180-67.22 \%$ perinatal deaths.

In the final analysis the number of babies survived was $59 / 180=32.77 \%$.

In authors previously reported study, there were 72 cases $(62.06 \%)$ with absent fetal heart sounds (IUD) at admission. Stillbirths were $10(8.6 \%)$ and neonatal deaths were another $10(8.6 \%)^{13}$

Perinatal mortality in authors previous series was 92/116 (79.3\%). In the present series and authors previous study, the PNM has been high.

Mukherjee S, Mumbai, reported in 318 cases, 68\% PNM. Mrinalini Mitra 2014-2015, reported a PNM of $63.79 \%$. Chhabra SA et al in 2014 from Wardha, reported in 667 cases of placental abruption, in 211 (32.5\%) perinatal deaths occurred. ${ }^{1,14,15}$

\section{Prematurity increases the PNM}

In this study the preterm deliveries were $79.33 \%$, which predisposes to enhanced PNM. Preterm deliveries $76.72 \%$ were reported in our previous study. ${ }^{13}$ Preterm birth ( $<37$ weeks) the majority of studies reported between 40 and $60 \%{ }^{3}$ Spontaneous preterm births due to abruption is thought to be the result of bleeding from the separation of the placenta which irritates the uterine lining and stimulates contractions which progress into preterm labour. $^{16}$

Although more than half $(55 \%)$ of excess perinatal deaths associated with abruption are attributed to preterm birth, the elevated risk of perinatal mortality remains significant even after adjusting for preterm delivery and growth restriction. ${ }^{2}$ Still births at admission, and neonatal deaths due to intra uterine hypoxia should account for the rest.

However, even term babies with normal birth weight have a 25-fold higher mortality with abruption. ${ }^{17}$ Approximately $10 \%$ of all preterm births and up to one third of all perinatal deaths are caused by placental abruption. ${ }^{19,20}$ 


\section{The increased need to perform abdominal delivery}

The total number of caesarean deliveries were $66 / 180-$ $(36.66 \%)$, number of vaginal deliveries were 114 $(63.33 \%)$ in the study. Of the 667 women with placental abruption, 373 (55.93\%) delivered vaginally and 294 $(44.07 \%)$ had C. section. ${ }^{1}$

Placental abruption was of mixed variety in $271(40.6 \%)$, $213(32 \%)$ had revealed haemorrhage and $183(27.4 \%)$ women had concealed abruption in this series. ${ }^{1}$

In countries that reported low usage of cesarean in cases with abruption (25-40\%) also typically reported higher perinatal mortality (40.4-67.9\%), indicating possibly low resource settings. ${ }^{21-23}$

\section{Urgent transfusion of blood products}

The number of patients who received blood transfusions were $105(58.3 \%)$, number of patients who received fresh frozen plasma, FFP transfusions were $65-36.11 \%$. This is one of the parameters to diagnose severe abruption.

\section{Hypertensive disorders complicating pregnancy in abruption placenta}

The number of cases with hypertension complicating pregnancy were $102-57 \%$, severe preeclampsia in $32 / 102 \%$. This is similar to our previous study $68 / 116$, $(58.62 \%)$ had preeclampsia. Saeed M, from Pakistan reported HDP-50\% in abruption cases. HDP, preeclampsia and gestational hypertension, were reported in $50 \%$ and $61.2 \% .^{22-24}$

\section{CONCLUSION}

The management and maternal mortality in this study are indicative of the obstetric care in a tertiary teaching public sector hospital. The doctors are experienced to manage these complicated cases. Given better transfusion facilities the mortality can be reduced further.

Funding: No funding sources

Conflict of interest: None declared

Ethical approval: The study was approved by the Institutional Ethics Committee

\section{REFERENCES}

1. Chhabra SA, Pandit V, Gosavi M. Placental abruption: a persisting killer. Int J Reprod Contracept Obstet Gynecol. 2014;3:604-9.

2. Ananth CV, Lavery JA, Vintzileos AM. Severe Placental Abruption: Clinical Definition and Associations with Maternal Complications. Am J Obstet Gynecol. 2016;214:272.e1-272.e9.

3. Downes KL, Grantz KL, Shenassa ED. Maternal, Labor, delivery, and perinatal outcomes associated with placental abruption: a systematic review. Am J Perinatol. 2017;34(10):935-57.

4. Ananth CV, Vintzileos AM. Maternal-fetal conditions necessitating a medical intervention resulting in preterm birth. Am J Obstet Gynecol. 2006;195(6):1557-63.

5. Ananth CV, Smulian JC, Vintzileos AM. Ischemic placental disease: maternal versus fetal clinical presentations by gestational age. J Matern Fetal Neonatal Med. 2010;23(8):887-93.

6. Ananth CV, Vander Weele TJ. Placental abruption and perinatal mortality with preterm delivery as a mediator: disentangling direct and indirect effects. Am J Epidemiol. 2011;174(1):99-108.

7. Ananth CV, Wilcox AJ. Placental abruption and perinatal mortality in the United States. Am J Epidemiol. 2001;153:332-7.

8. Rasmussen S, Irgens LM, Bergsjo P, Dalaker K. Perinatal mortality and case fatality after placental abruption in Norway 1967-1991. Acta Obstet Gynecol Scand. 1996;75:229-34.

9. Raymond EG, Mills JL. Placental abruption. Maternal risk factors and associated fetal conditions. Acta Obstet Gynecol Scand. 1993;72:633-9.

10. Tikkanen M, Luukkaala T, Gissler M, Ritvanen A, Ylikorkala O, Paavonen J, et al. Decreasing perinatal mortality in placental abruption. Acta Obstet Gynecol Scand. 2013;92:298-305.

11. Devabhaktuni P, Addula MR, Ponnur M, Kasu B, Ramakoti S, Reddy H. Management of eclampsia and imminent eclampsia, maternal and perinatal outcome in 666 cases-2003-2007 at Government Maternity Hospital in Hyderabad. Open J Obstet and Gynecol. 2017;7(2):193-207.

12. Devabhaktuni P, Vemuri UR, Allani P, Ponnuru M, Gogineni S. Comprehensive analysis of 1000 labour inductions with vaginal misoprostol. Gynecol Obstet Open Acc: 2018;OBOA-128.

13. Devabhaktuni P, Nagasree MGS. Abruptio placentae 116 cases: role of PGE1 in cervical ripening and induction of labor. Open $\mathbf{J}$ Obstet Gynecol. 2008;8:585-97.

14. Mukherjee S, Bawa AK, Sharma S, Nandanwar YS, Gadam M. Retrospective study of risk factors and maternal and fetal outcome in patients with abruptio placentae. J Natural Sci Biol Med. 2014;5:425-8.

15. Mitra M, Rao B. A one-year cross sectional analysis of abruptio placenta in a tertiary care hospital. Int $\mathbf{J}$ Recent Sci Res. 2016;7:8984-6.

16. Romero R, Kusanovic JP, Chaiworapongsa T, Hassan SS. Placental bed disorders in preterm labor, preterm PROM, spontaneous abortion and abruptio placentae. Best Pract Res Clin Obstet Gynaecol. 2011;25(3):313-27.

17. Ananth CV, Getahun D, Peltier MR, Smulian JC. Placental abruption in term and preterm gestations: evidence for heterogeneity in clinical pathways. Obstet Gynecol. 2006;107:785-92.

18. Oyelese Y, Ananth CV. Placental abruption. Obstet Gynecol. 2006;108:1005-16. 
19. Qamarunisa MH, Frequency AM. maternal and fetal outcome of abruptio placenta in a rural medical college hospital, Mirpurkhas Sindh. Pak J Med Sci. 2010;26:663-6.

20. Naz F, Shakoor U, Sharafat S, Khan S, Iqbal K, Zareen A. Comparison of pregnancy outcome in placenta previa versus placenta abruption. Pakistan J Med Health Sci. 2010;4:149-52.

21. Saeed M, Rana T. Fetomaternal outcome in pregnancies complicated with placental abruption. Pakistan J Med Health Sci. 2011;5:140-3.

22. Saeed M, Rana T. Fetomaternal outcome in pregnancies complicated with placental abruption. Pak J Med Health Sci. 2011;5:140-3.

23. Baumann P, Blackwell SC, Schild C, Berry SM, Friedrich HJ. Mathematic modeling to predict abruptio placentae. Am J Obstet Gynecol. 2000;183:815-22.

24. Pariente G, Shoham-Vardi I, Kessous R, Sherf M, Sheiner E. Placental abruption as a significant risk factor for long-term cardiovascular mortality in a follow-up period of more than a decade. Paediatr Peri Epidemiol. 2014;28:32-8.

Cite this article as: Devabhaktuni $\mathrm{P}$, Konkathi AK. Placental abruption an obstetric emergency: management and outcomes in 180 cases. Int J Reprod Contracept Obstet Gynecol 2020;9:3188-95. 